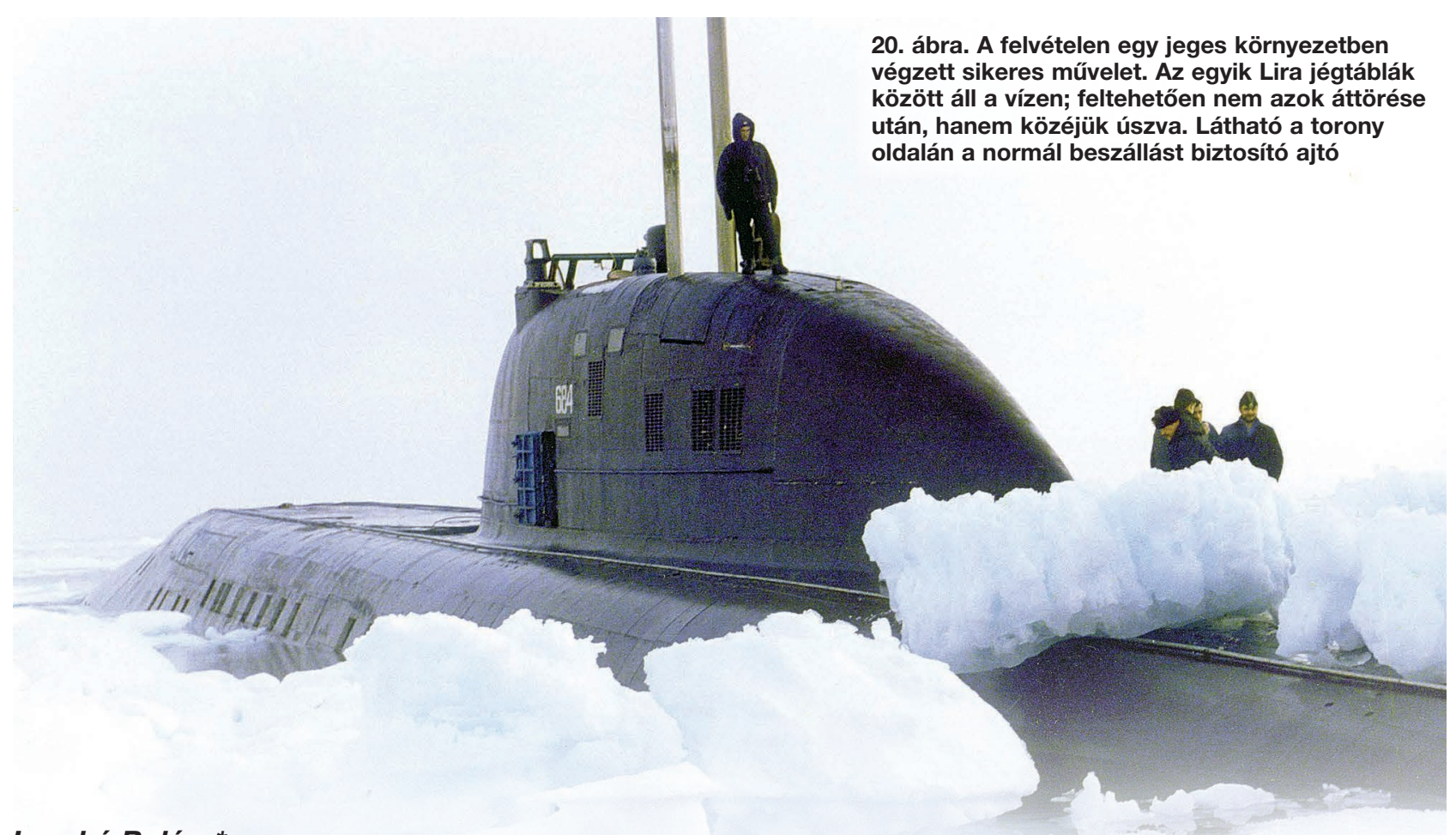

\title{
A szovjet Lira (NATO-kód: Alfa) osztályú atom-tengeralattjárók m.ress
}

\begin{abstract}
A sorozat előző részeiben Projekt 705 Лира (Líra) jelölésű, a maga korában forradalmian új technológiájú tengeralattjáró tervezését, kivitelezését, prototípusait és fegyverrendszerét mutattuk be. A Lira megszületését 1960-ban a legmagasabb szintű (SzKP KB - SzMT közös) határozat döntötte el. A záró epizód a további egységekkel és a hajóosztály sorsával foglalkozik.
\end{abstract}

\section{A K-316-OS TENGERALATTJÁRO}

A szolgálatba lépés szerinti következő Lira a K-316-os volt, amelynek legénységét már 1967-ben kijelölték, de építését csak 1969. április 26-án kezdték meg Leningrádban - tehát Projekt 705 típusú volt. A K-64-eshez hasonlóan ezt a példányt is északra szállították felszerelésre, és szintén az osztály első hajója miatt volt csúszásban az építkezés. Az utat így csak 1974. február 24-én kezdhették meg Szeverodvinszkbe, és bár a kihajózás a szállítódokkban éjjel történt, ez egy ún. fehér éjszaka volt, vagyis jól láthatta a Néva partján a lakosság a műveletet. A tengeralattjáró próbáit 1975 és '78 között végezték, köztük az utóbbi év szeptember 3-ától az állami átvételi teszteket. Ennek során egy alkalommal, amikor 40 csomóval haladtak, igen egyedi probléma lépett fel, ugyanis egy hibás („beragadt”) vezérlőrendszeri beállítás nem engedte leterhelni a turbinát.
A személyzet végül úrrá lett a helyzeten és kijavította a hibát. (A túl hosszú ideig fennmaradó tempó nem a reaktort magát terhelte meg, hiszen abban évekre elég energia volt, hanem a kapcsolódó gépészetet.) Az átvételre végül 1978. szeptember 30-án került sor, és a K-316 november 23-án, Zapadnaja Licában lépett a 6. hadosztály kötelékébe. 1979ben az 1. flottilla ,jó” minősítését kapta a hajó, majd decemberben egy gyakorlaton az első helyen végzett. 1980. szeptember 4-én a K-136-os úton volt egy másik kikötőbe, amikor 38,8 csomós sebességnél és $100 \mathrm{~m}$ mélyen letért a kijelölt útvonalról, és - mivel immár a part felé haladt -, a sekélyes vízben veszélyesen közel került az egyre „emelkedő" tengerfenékhez. A hajó végül $3 \mathrm{~km}$-re a parttól, sérülés nélkül emelkedett a felszínre.

1981-ben ez az egység is részt vett az „Észak-81” elnevezésű hadgyakorlaton, mégsem említik a másik három résztvevő 705-össel együtt. Ez az egység talán külön végzett feladatokat. Egy 1982-es, „jó” minősítésű utat követően '83-ban (közelebbi időpont nem ismert, de valószínűleg az év elején) a K-316-os az arktiszi régióban gyakorlatozott, amikor a jégtakaró alatt haladva zárlatos lett a meghajtás fő vezérlőpultja. A hajó letért az útvonalról, de sokkal nagyobb baj volt, hogy lassan emelkedni kezdett, és félő volt, hogy jégnek ütközik. A személyzet gyorsan eloltotta a tüzet, és még biztonságos mélységben, a merülési kormány nélkül is stabilizálta a hajót. Csakhogy a reaktorvé-

\footnotetext{
Fizikus (MSc). ORCID: 0000-0002-1005-6951
} 


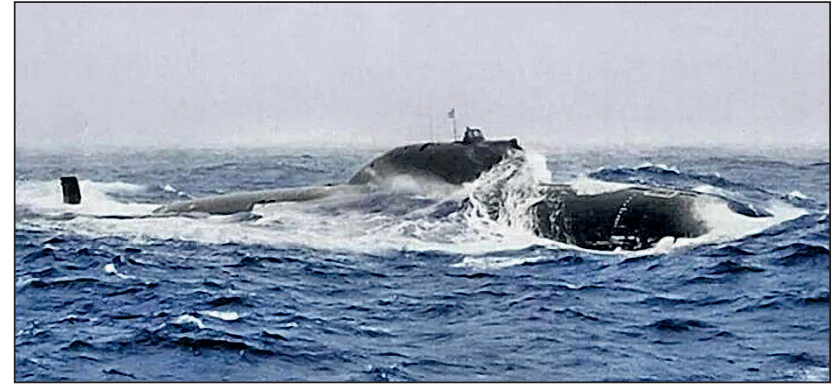

21. ábra. Kellemetlen időjárási viszonyok között szükség volt a szélvédőre a kicsi, alacsony Projekt 705-ösökön, noha a felszínen csak kb. 12 csomóra volt képes a típus

delmi automatika műveletei miatt a vákuum megszűnt a kondenzátorban, a szekunder köri gőzt alakította vissza vízzé. Vissza kellett állítani a kondenzátorban a vízforgalmat a megfelelő szintre. Ennek érdekében kézi szelepnyitásokkal a turbinában maradt nedves gőzt vezették be, és ezzel sikerült a kondenzátort életre kelteni. A tengeralattjáró ezt követően elindulhatott a jég alól a nyílt vízre, mivel felszínre kellett emelkednie ahhoz, hogy a tűz miatt keletkezett füstöt kiszellőztessék. A jégtakarót 20 óra alatt hagyták el, addig a személyzet légzésvédő maszkot viselt. Az utólagos vizsgálat megállapítása szerint a tengerészek az összes elhárítási akciót tökéletesen hajtották végre.

A tengeralattjáró 1983 áprilisában testvérhajóival, a $\mathrm{K}-432$-essel, a K-493-assal és a K-463-assal együtt az „Óceán-83" elnevezésű gyakorlaton vett részt, majd egy másik hadgyakorlatot is teljesített. Abban az évben ismét volt egy „jó" minősítésű útja. 1984-ben 10 napos késéssel, december 25-én egy küldetésre kifutott a hajó, de 27-én már vissza is tért a bázisra, mivel a turbina hibája miatt nagy mennyiségű tápvizet vesztett. 1985 nyarán a Fehérés a Norvég-tengeren új eszközöket próbáltak ki rajta, a következő két évben pedig éles készenlétben állt. 1987. december 20-án javításra kivonták az aktív állományból, és a következő év augusztusában vontatva a Szvjatonosszkijöbölbe szállították, ahol megkezdték a reaktor aktív zónájának kiszerelési előkészületeit. A múveletet - a szovjet flottában a folyékony fém hűtésű reaktorok közül elsőként 1990 februárjában végrehajtották. Április 19-én végleg kivonták az állományból, de legénységét csak öt évvel később oszlatták fel. A hajót ezt követően Szeverodvinszkbe vontatták, ahol a Szevmas hadiipari vállalat lebontotta.

\section{A K-432-ES TENGERALATTJÁRO}

A K-432-es 1978 utolsó napján állt szolgálatba. Ez a tengeralattjáró a második Projekt $705 \mathrm{~K}$ volt, amelyet 106-os gyári számmal, 1968. november 12. és 1977. március 11. között építettek. A tényleges készítés - a K-64-es hibáit is figyelembe véve - 1974 áprilisától zajlott. Az „új” hajót 1980. március 30-án osztották be a készenléti erőkhöz. Első katonai útján jég alatti műveleteket végzett, valamint - elvileg első ízben a szovjet tengeralattjárók közül - müholdas navigációt használt. A K-123-as és K-373-as hajókkal együtt részt vett az „Észak-81” hadgyakorlaton, majd az év október 12-én a Zvezdocska gyárba állt be karbantartásra. A javításokat követően, 1982. március 12-én a K-432-es elnyerte az 1. flottilla "legjobb torpedótámadásért” járó kitüntetését. Az „Óceán-83” hadgyakor-

22. ábra. A K-373-as, 1990 után

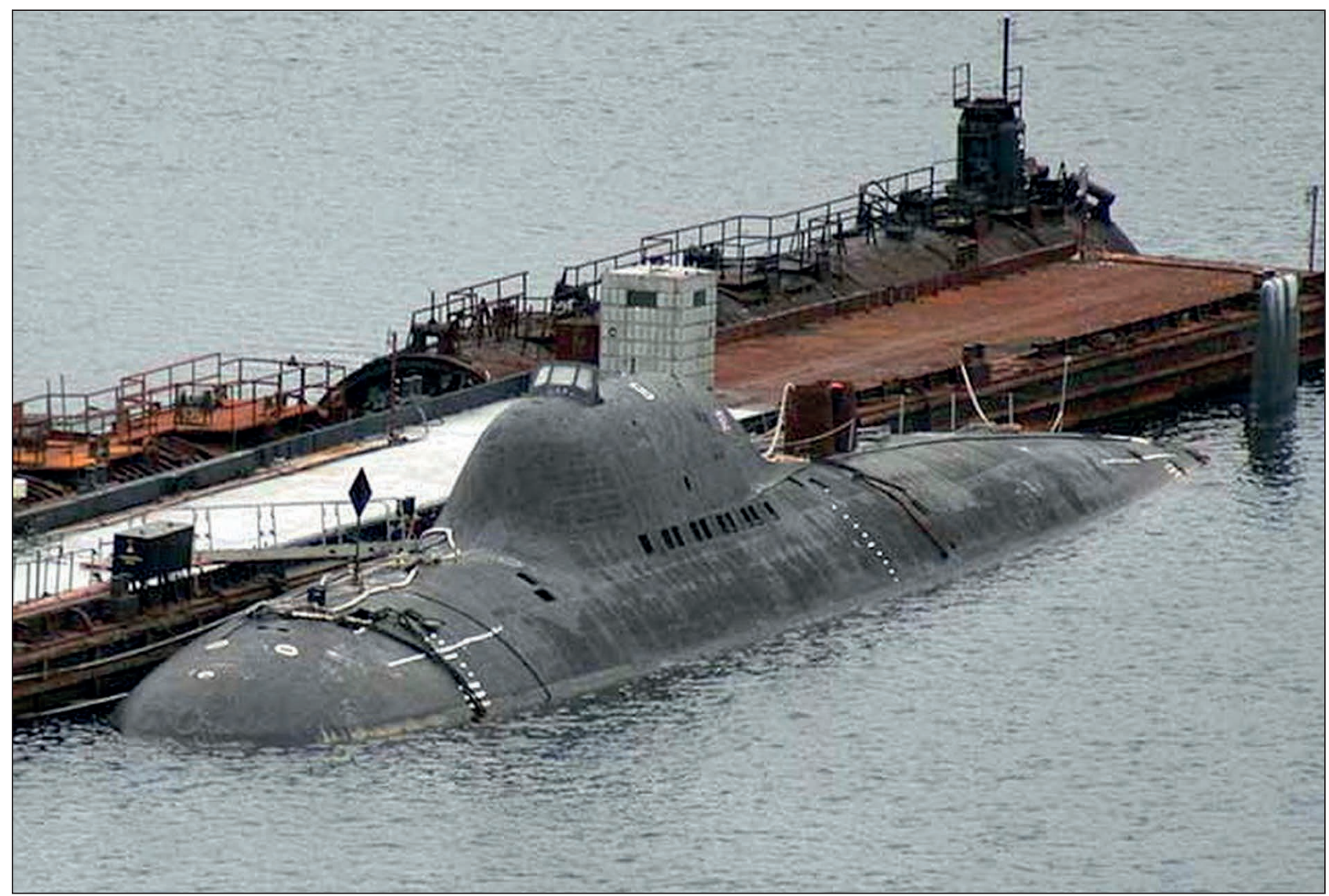




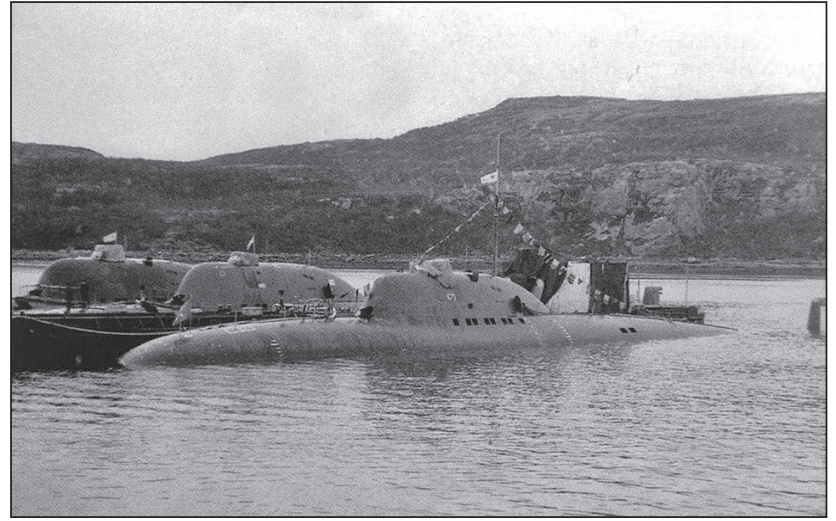

23. ábra. A Lopatkina-öbölben álló, fellobogózott K-493-as, 1991 októberében

laton való részvétel után a hatodik őrjárat következett, ami - egy orosz forrás szerint, amelyet csak az érdekesség kedvéért idézünk - a korábbiaknál eseménydúsabbra sikerült. Egy gyakorlatot követően a K-432-es a felszínre emelkedett, ahol kevesebb, mint 100 m-re tőle egy amerikai harckocsi-partraszállító hajó tartózkodott. Az amerikai hajóról fotózni kezdték a tengeralattjárót. A szovjetek szerint a kis távolsággal megsértették a tengeri összeütközések elkerülése érdekében kötött amerikai-szovjet egyezményt. Ráadásul a K-432-es meghibásodás miatt nem tudott lemerülni, és az amerikaiak még egy csónakot is elindítottak, hogy szorosan megközelítsék a tengeralattjárót. Ez idő alatt végig veszélyesen közel maradtak. Végül a szovjet egységnek sikerült lemerülnie és elhagyta a helyszínt. (A történet valóságtartalma erősen kérdéses.)

1984-ben a legénység az 1. flottilla tagjai között szocialista versenyt kezdeményezett, amelyet mind a harci, mind a politikai képzés terén „kiváló” eredménnyel zárt. Ezt követően eseménytelen, harci készenléttel töltött évek következtek, majd a Szovjetunió összeomlása miatt a K-432-est 1990. április 19-én kivonták a szolgálatból. Négy év múlva a Szevmas hadiipari vállalathoz került, ahol 1996-ban lebontották.

\section{A K-373-AS TENGERALATTJÁRÓ}

A következő szolgálatba állt Projekt 705-ös a K-373-as volt (gyári száma 910.), amely 1972. június 26. és 1978. április 19. között épült Leningrádban. A felszelést követően 1979. december 29-én vette át a haditengerészet, és a következő év közepétől már bevetésre készen állt. Első katonai útja során tengeralattjáró-elhárító repülőgépekkel működött együtt, majd - a szovjet flotta történetében először - meghibásodás miatt a víz alatt indította újra meghajtórendszerét. Az „Észak-81” nevű hadgyakorlaton történt szereplése után, majd 1982-ben is egysége legjobb hajója lett, és elnyerte a „kiváló” minősítést. Az év végén hajóosztálya számára jelentős fegyvertényként könyvelhették el, hogy a K-373-as 21 óra 40 percen keresztül követett egy ellenséges tengeralattjárót, ebből 20 percig észrevétlenül. Az akciót csak a flottavezetés parancsára szakították meg, az üldözőbe vett egység képtelen volt lerázni a gyors szovjet SSN-t. Az „Atlanti-84”-es gyakorlat után, az év június 22-én, a Motov-öbölben, felszínen haladva, rossz időjárási körülmények között a K-140-essel, az egyetlen Projekt 667AM (Yankee II) osztályú SSBN-nel ütközött össze. A baleset során csak kis mértékű kár keletkezett. 1985. június 22-én a legjobb torpedótámadásért járó díjat kapta meg a K-373, ezt követően 1990-ig a készenléti erőknél szolgált, és bár még megkezdték nagyjavítását, társaihoz hasonlóan április 19-én kivonták a flottától.

\section{A K-493-AS TENGERALATTJÁRO}

Ismét egy 705K következett a szolgálatban, a K-493-as. A 107-es gyári számú tengeralattjáró építését 1972. január 21-én kezdték. A befejezésre 8 évvel és 9 hónappal később került sor, és 1981. szeptember 30-án adták át a tengerészetnek, ahol november 23-án regisztrálták az 1. flotilla tagjaként 1982 végén máris a Zvezdocska üzem javította a hajót, majd az „Oceán-83” hadgyakorlaton vett részt. Negyedik útján, 1984-ben az UERV-K légszűrő meghibásodása miatt a $\mathrm{V}-64$ jelű, vészhelyzeti szűrőlemezeket használta a személyzet a helyiségekben, de így is magas szén-dioxid tartalmú levegőt lélegeztek be.

A K-493-as sem kerülte el a reaktorbalesetet, de ez az esemény kevésbé bizonyult súlyosnak, mint a sorozatban korábban említett másik kettő, illetve a K-27-es esete. A baleset során valamennyi eutektikum kijutott a reaktor rekeszébe, de a vészhelyzet megálításához elegendőnek bizonyult a hajó saját személyzetének közbelépése és az általuk végzett dekontaminálás. Ezzel együtt még a következő úton is, ahol egyébként jég alatti műveleteket végeztek, a hajótestben magas volt a radioaktív aeroszolok szintje. 1987-89 között, társaihoz hasonlóan a készenléti csoportban volt a hajó, majd 1989 májusában újabb súlyos hiba történt a meghajtásban. Ez az eset is megmutatta, hogy a BM-40A és gépei is megbízhatatlanok voltak. A kondenzátor javíthatatlanul vesztette a tápvizet, ezért - hogy a feladatot ne kelljen megszakítani - az a veszélyes és elképesztő döntés született, hogy a személyzet kézzel, vödrökkel(!) töltse fel a rendszert. Ezt követően a K-493-ast Gremihába vontatták, ahol a reaktort eltávolították, és magát a tengeralattjárót visszavitték a Lopatkina-öbölbe. 1990. április 19-én leszerelték, és 1996 után szétbontották.

\section{A K-463-ES TENGERALATTJÁRÓ}

Az utolsónak épített Projekt 705-ös a K-463-as tengeralattjáró volt. A 915-ös gyári számú egység építését 1975. június 26-án kezdték el, majdnem hat évvel később, 1981. március 31-én készült el és december 30-án állt szolgálatba. A testvérhajóival azonos alakulatba sorolt hajó első útján - amelyet 1982. április 16-án kezdett meg - mélymerülési próba közben súlyosan megrongálódott. Az első rekeszbe víz tört be, ami az ott található elektromos eszközökben zárlatot okozott, és emiatt tűz ütött ki. Bár a tüzet gyorsan eloltották és a hajó a felszínre emelkedett, újabb baj történt. Időközben a legénység megpróbálta megjavítani a vízbetörés helyét a hajó orrán, és eközben ketten a vízbe sodródtak. A mentésüket megkísérlő három társuk szintén, őket azonban biztonsági kötelek rögzítették a K-463-ashoz. Az ötből négy embert sikerült kihúzni, de ötödik társuk életét vesztette. Április 19-én - az utat sikertelennek minősítve - visszatérésre utasították a hajót. Az "Óceán-83" hadgyakorlat után a hajó egy 10 nappal meghosszabbított utat tett meg, amellyel elnyerte a "kiváló” minősítést. Az egység 1986-ban és '87-ben, a tengeralattjáró-elhárító gyakorlatok alapján az egész szovjet flotta legjobbja lett. Ahogyan a többi Lirát, ezt a példányt is 1990. április 19-én vonták ki a haderőből, és a Szevmas hadiipari vállalat 1995 után bontotta szét. 


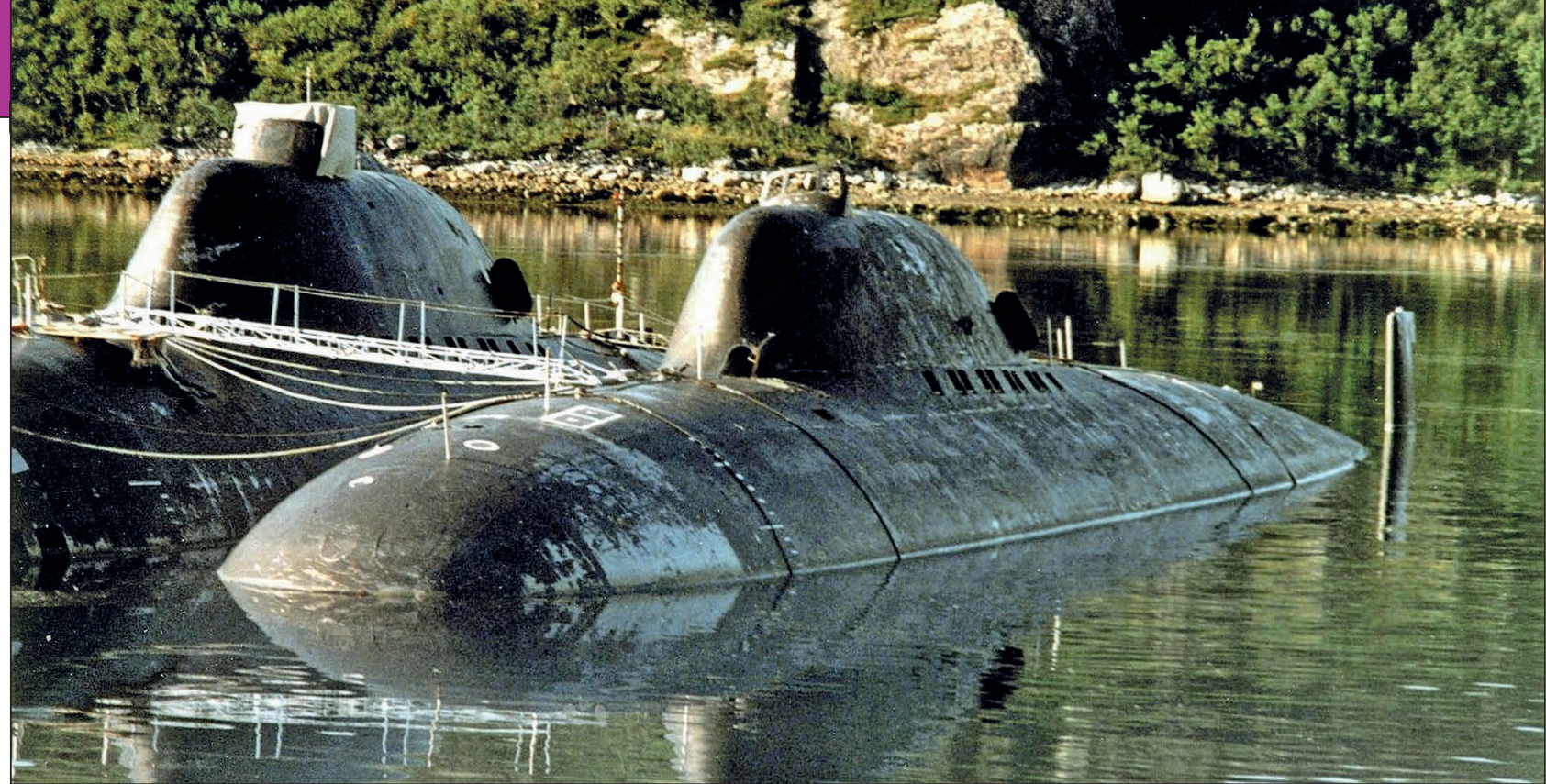

24. ábra. A bal oldalon a K-123-as Lira, a másik egységről nincs adat. A felvétel Zapadnaja Licában készült

1. táblázat. A Lira (NATO kód: Alfa) osztályú atom-tengeralattjáró múszaki adatai

\begin{tabular}{|c|c|}
\hline vízkiszorítás a felszínen & $2300 \mathrm{t}(2280 \mathrm{t})$ \\
\hline vízkiszorítás lemerülve & $3150 \mathrm{t}(3125 \mathrm{t})$ \\
\hline teljes hosszúság & $81,4 \mathrm{~m}(79,6 \mathrm{~m})$ \\
\hline $\begin{array}{l}\text { legnagyobb szélesség } \\
\text { törzs } \\
\text { (hátsó merülési } \\
\text { kormányoknál) }\end{array}$ & $\begin{array}{r}9,5 \mathrm{~m} \\
13,5 \mathrm{~m}\end{array}$ \\
\hline merülés & $6,24 \mathrm{~m}$ \\
\hline maximális sebesség & $\begin{array}{l}\text { 40,2 csomó (40,3 csomó) } \\
\text { nem hivatalosan } 41 \text { csomó }\end{array}$ \\
\hline $\begin{array}{l}\text { maximális sebesség a } \\
\text { felszínen }\end{array}$ & 12-14 csomó \\
\hline
\end{tabular}

A táblázat a Lira néhány, a szövegben nem említett adatát is tartalmazza. A 705K-k rövidebbek társaiknál. Az eltérő konstrukciójú BM-40A esetén a törzset nem kellett utólag meghosszabbítani az OK-550 fütőtestei miatt, ezért a tömegük is kisebb egy árnyalatnyival, de ezt általában nem szokták elkülöníteni. A táblázatban a 705K adatait zárójelben közöljük.

\section{Az OSZTÁLY LESZERELÉSE}

Egy 2002-ben, az Egyesült Államokban készült tanulmány részletesen foglalkozik az Alfák reaktoraival, elsősorban azok leszerelésével, illetve üzemanyaguk sorsával. Ez utóbbi különösen érdekli az USA-t, mivel elvileg jó alapanyag lehet atomfegyverek számára a fegyvertisztaságúra dúsított urán a fütőelemekben.

Az üzemanyagot eredetileg Kazahsztánban az Ulba Kohászati Művek készítette az osztály számára, de később ezt a feladatot a legnagyobb szovjet-orosz üzem, az Elektrosztáli Gépgyár vette át. $A$ folyékony fém hűtésű reaktorba egyben rakták be a üzemanyag-rudakat, és ahogy korábban említettük, a szerkezetet (tartály, szabályozó rudak, üzemanyag), ezt követően már csak egyben, magával a reaktortartállyal együtt lehetett kiemelni a rendszerből. Ezt az egységet nevezték angolul RRCU-nak, azaz Removable Reactor Core Unitnak (kb. [egyben] kivehető reaktorzóna). Kivételkor a szabályozórudakat mozgató mo- torokat levágták, helyüket rozsdamentes acélból készült burkolattal pótolták, amit oda is hegesztettek, nehogy véletlenül kivehessék a rudakat. Az így előkészített RRCU-t friss folyékony ólom-bizmut keveréket tartalmazó acéltartályba helyezték, majd hagyták megszilárdulni az eutektikumot. A nedvesség kizárására bitumennel vették körül a tartályt, amelyre $3 \mathrm{~kW}$-os hőteljesítmény-limit vonatkozott. A tartályokat a szovjet flotta Gremiha bázisán, egy 10 egységes tároló építményben helyezték el. Ez a tároló eredetileg csak egy átmeneti időszakra épült, de már 2002-ben is közel 10 éve voltak benne egyes RRCU-k. Ezért kérdéses az RRCU-k jelenlegi fizikai állapota például korrózió tekintetében, de a földrengés vagy tűz elleni védelem is problémás. A lopás elleni biztonsági intézkedések is alacsonyabb szintüek a kelleténél. A tengerészeti reaktorok magas dúsítású urán üzemanyaguk miatt egyébként fontosabb célpontot jelentenek az esetleges tolvajoknak, mint az erőmüvek kiégett kazettái. Ennek oka, hogy az uránt könnyebb kivonni az előbbiekből, mint a keletkezett plutóniumot az utóbbiakból. Valamennyire megnyugtató azonban, hogy amíg a fütőelemek az RRCU-ban vannak, addig elég nehéz onnan kiemelni azokat különleges eszközök nélkül, és magát az RRCU-t egyben ellopni sem egyszerű művelet. Napjainkban sajnos annak is megvan az esélye, hogy az RRCU-k véletlenül kritikussá válnak. Ennek oka, hogy a különböző kémiai és más degradációs folyamatok hoszszabb távú hatása nem ismert.

Az Alfák kivonásukat követően Szeverodvinszkbe kerültek, ahol leszerelték, majd az RRCU eltávolítása után szétvágták őket. Orosz állítás szerint a teljes bontás nullszaldós, de ez kétséges, mivel a speciális szerszámok és eszközök mellé az

25. ábra. A 6 db Projekt 705-ösből 5 db Zapadnaja Licában kikötve, sorsára vár. A hajókhoz villamos kábelek vezetnek, külső gőzforrásuk nincs

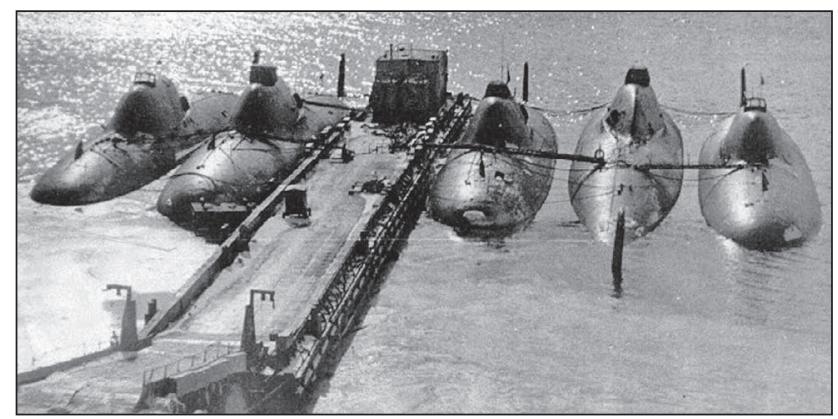




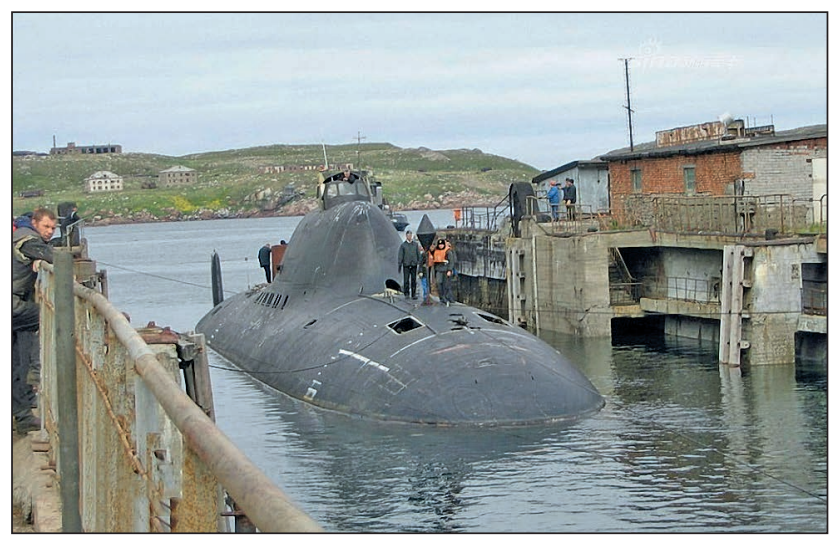

26. ábra. A B-123-as dokkba állása közben. A rajta lévő személyek magassága jól mutatja, hogy SSN létére mennyire kicsi a Projekt 705-ös

osztály titán törzse ismét csak különleges berendezések beszerzését igényli például a szétvágáshoz, ellentétben az egyszerübben bontható, acéltestű típusokkal. A Szevmas tengeralattjárónként akár több millió dollárt is veszíthet a műveleten. (A K-463 esetében a konkrét összeg 2000-es évek körüli áron 1 milliárd rubel, azaz 2,5 millió dollár volt.)

A K-64-es reaktorbalesetét követően a kivágott reaktorszekciót a szovjetek először a tengerbe akarták temetni, de az 1972-ben, a járművek által okozott tengeri szennyezéseket korlátozó, Londonban kötött egyezményt maguk is aláirták, és azt nem kívánták ilyen súlyosan megsérteni. A Kara-tengerre bárkán szállított hulladékot ezért előbb a Zvezdocska gyárba vitték tárolás céljából, majd végül tovább Gremihába, a többi RRCU későbbi helyére. Végül valószínűleg a gremihai tárolóba került az összes Alfából kiemelt RRCU. Itt végezte a K-27-es két reaktora is, tehát elvileg összesen $9 \mathrm{db} \mathrm{RRCU}$ található benne. A reaktorszekciókat - immár lényegében üresen -, más báziso(ko)n tárolják, a tengeralattjárók maradékát pedig fémhulladékként újrafeldolgozták.

\section{KöVETKEZTETÉS}

A Projekt 705-ösök pályafutása nem volt zökkenőmentes. A számos korábban nem, vagy alig alkalmazott technológia miatt sok és súlyos probléma adódott az osztállyal

\section{7. ábra. Már leürített szárazdokkban áll a láthatóan} leamortizálódott B-123-as

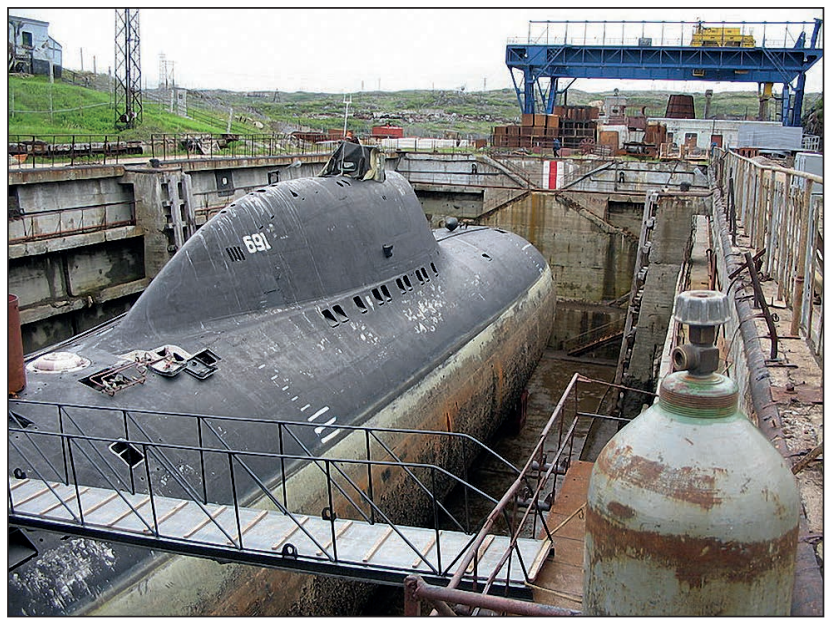

kapcsolatban - amiket leglátványosabban a K-64-es története bizonyított. Bár az orosz források kiemelik a világszinten is egyedülálló képességeket, és hogy a (reaktor)balesetek ellenére csak egyetlen halálos áldozata volt a Lira szolgálatának (a K-463-as baleseténél), mégis a mérleg nehezen tekinthető pozitívnak. A teljes harcképesség elérése az 1980-as években már az egy generációval fejlettebb ellenséges fegyverekkel szemben történt. A program költségei is magasak voltak, az üzemeltetés pedig a szokatlan reaktor és egyedi elektronika miatt nehézkes.

\section{FORRÁSOK}

„Проект 705 и 705К «Лира» (NATO - “Alfa”)”. Letöltve: 2019.09.16. http://www.deepstorm.ru/DeepStorm. files/45-92/nts/705/list.htm;

„Проект 705 «Лира» АТОМНАЯ ПОДВОДНАЯ ЛОДКА - Project 705 (ALFA class) attack nuclear submarine". Letöltve: 2019.09.16. http://xn----7sbb5ahj4aiadq2m. xn--p1ai/guide/navy/pl/mpl/705.shtml;

„Nuclear Submarine Project 705 (705K)”. Letöltve: 2019.09.16. http://bastion-karpenko.ru/705-apl/;

Lobner, Peter. 60 Years of Marine Nuclear Power: 1955 2015 Part 3: Former Soviet Union \& Russia, 2015. Letöltve: 2019.09.16.

http://www.lynceans.org/wp-content/uploads/2015/09/

Part-3_Russia-60-yrs-of-marine-nuc-power.pdf;

Константин Ришес. „Субмарина-истребитель проекта 705" Letöltve. 2019.09.16. http://www.popmech.ru/ weapon/16141-submarina-istrebitel-proekta-705/;

Рябов Кирилл. „Скоростная «Лира»: АПЛ проекта 705” Letöltve: 2019.09.16. https://topwar.ru/36398skorostnaya-lira-apl-proekta-705.html;

„Проектные проработки по АПЛ проекта 705 группы А.Б. Петрова" Letöltve: 2019.09.16.

http://www.deepstorm.ru/DeepStorm.files/45-92/ nts/705/pp705.htm;

Project 705 Lira Alfa class Attack Submarine (Nuclear Powered) Letöltve: 2019.09.16. http://www. globalsecurity.org/military/world/russia/705.htm;

„Nuclear-powered submarines. Project 705 Lira, Project 705K Lira, NATO: Alfa Class" Letöltve: 2019.09.16.

http://russianships.info/eng/submarines/project_705.htm; „SSN - Projekt 705 Lira (kód NATO: Alfa), ПЛАТ - Проект 705 Лира" Letöltve: 2019.09.16. http://en.valka.cz/ topic/view/893/SSN-Projekt-705-Lira-kod-NATO;

Вольф Мазур. „ТИТАНОВЫЙ МЕЧ РОССИИ, КОТОРЫЙ МЫ ПОТЕРЯЛИ" Letöltve: 2019.09.16.

http://www.liveinternet.ru/users/ertata/post224574532/;

„Атомная подводная лодка Лира (проект 705)” Letöltve: 2019.09.16. http://topgun.rin.ru/cgi-bin/index1. pl?a=units\&field=91\&unit=2308;

„Легенда флота: атомная подлодка «Лира»" Letöltve: 2019.09.16. http://army-news.ru/2013/11/legenda-flotaatomnaya-podlodka-lira/;

Антон Мардасов. „АПЛ «Лира»: возвращение «подводного истребителя»" Letöltve: 2019.09.16. http://svpressa.ru/war21/article/143069/;

Антон Мардасов. „Чудо инженерии - подлодки проекта 705 Лира” Letöltve: 219.09.16.

http://www.veteranrosatom.ru/articles/articles_991.html;

"Nuclear-Powered Ships" Letöltve: 2019.09.16.

http://www.world-nuclear.org/information-library/ non-power-nuclear-applications/transport/nuclearpowered-ships.aspx. 